\title{
RIWAYAT MAKANAN YANG MENINGKATKAN ASAM LAMBUNG SEBAGAI FAKTOR RISIKO GASTRITIS
}

\author{
Arikah, Lailatul Muniroh \\ Departemen Gizi Kesehatan, Fakultas Kesehatan Masyarakat, Universitas Airlangga, Surabaya \\ lailagizi@gmail.com
}

\begin{abstract}
ABSTRAK
Gastritis merupakan salah satu gangguan pencernaan akibat pola makan. Hampir 10 persen penduduk dunia menderita gastritis. Di Indonesia, angka kejadian gastritis sebesar 40,8 persen. Pola makan yang merupakan faktor pemicu gastritis adalah konsumsi tinggi protein dalam menu harian, kebiasaan konsumsi makanan pedas dan minum kopi. Penelitian ini bertujuan mengidentifikasi faktor risiko riwayat konsumsi makanan yang berpotensi meningkatkan keasaman lambung terhadap kejadian gastritis. Penelitian observasional dengan desain case control dilakukan pada 32 responden terdiri dari 16 responden gastritis dan 16 responden non gastritis. Variabel bebas penelitian meliputi riwayat konsumsi protein, riwayat konsumsi sambal, dan kebiasaan minum kopi. Pengambilan sampel dilakukan dengan metode systematic random sampling dan dengan menggunakan form Dietary History dan form Food Frequency semi quantitative. Hasil penelitian menunjukkan sebagian besar responden gastritis berjenis kelamin perempuan $(78,12 \%)$, berusia antara $20-30$ tahun $(40,63 \%)$, dan telah menderita gastritis $>3$ tahun $(43,75 \%)$. Berdasarkan uji statistik, variabel yang merupakan faktor risiko gastritis adalah frekuensi konsumsi susu $(p=0,034, O R=6,600)$ dan jumlah konsumsi sambal $(p=0,037, O R=11,667)$. Responden dengan riwayat frekuensi konsumsi susu sering, berisiko 6,6 kali lebih besar mengalami gastritis dibanding responden dengan riwayat konsumsi susu jarang, dan responden yang memiliki riwayat kebiasaan konsumsi sambal $>3$ sdt per konsumsi, berisiko 11,667 kali untuk menderita gastritis dibanding yang memiliki kebiasaan konsumsi sambal kurang dari itu. Saran untuk pasien gastritis sebaiknya membatasi konsumsi susu terutama bila bersamaan dengan makanan berat lain dan konsumsi sambal yang berlebihan, karena keduanya dapat menstimulasi produksi asam lambung berlebihan sehingga menimbulkan perlukaan pada dinding lambung.
\end{abstract}

Kata kunci: riwayat makanan, asam lambung, gastritis

\section{ABSTRACT}

\section{DIET HISTORY AS RISK FACTORS OF GASTRISTIC BY IMPROVING GASTRICT ACID}

Gastritis is a digestive disorder caused by diet. Nearly 10 percent of people worldwide suffer from gastritis. In Indonesia, the incidence of gastritis was 40.8 percent. Food consumption which is a trigger factor of gastritis are the high consumption of protein in the daily diet, spicy foods and drinking coffee. This study aimed to identify risk factors of food consumption history that could increase gastric acidity as a risk factor of gastritis. The observational study with case control design conducted to 32 respondents devided into 2 groups, gastritis and non-gastritis group. Independent variables were protein consumption history, consumption of chili sauce, and drinking coffee habits. Sampling has done using systematic random sampling and food history was assessed using Dietary History form and Food Frequency semi quantitative form. The results showed that most of the gastritis respondents were female $(78,12 \%)$, at the age range of $20-30$ years $(40,63 \%)$, and had suffered gastritis $>3$ years $(43,75 \%)$. The risk estimation results indicated that the significant variables as risk factors of gastritis were frequency of milk consumption $(p=0,034, O R=6,600)$ and the amount of chili sauce consumption $(p=0,037, O R=11,667)$. Respondents with frequent history of milk consumption had 6,6 times greater risk for experiencing gastritis than those infrequent history of milk consumption, and respondents who had history of chili sauce consumption habits $>3$ tsp per consumptionhad 11,667 times greater risk for experiencing gastritis than those who consumed chili sauce habits less than that. Patients with gastritis should limit their milk consumption especially when ate with other heavy foods; and also limit consumption of chili sauce because it can stimulate excessive production of gastric acid that can iritate the gastric mucosa.

Keywords: diet history, gastric acid, gastritis 


\section{PENDAHULUAN}

G astritis adalah salah satu gangguan pencernaan yang banyak diderita masyarakat dunia. Hampir 10persen penduduk dunia menderita gastritis. ${ }^{1}$ Berdasarkan penelitian $\mathrm{WHO}$, insiden gastritis di dunia telah mencapai sekitar 1,8-2,1 juta dari jumlah penduduk setiap tahunnya. Di Indonesia angka kejadian gastritis cukup tinggi. Persentase angka kejadian gastritis di Indonesia menurut WHO adalah 40,8persen ${ }^{2}$ Berdasarkan data Depkes RI dari WHO pada tahun 2004 menyebutkan bahwa Indonesia berada pada urutan keempat menurut jumlah penderita gastritis setelah Amerika Serikat, Inggris dan Bangladesh dengan jumlah penderita gastritis sebanyak 430 juta orang. Berdasarkan penelitian yang dilakukan oleh Kemenkes RI, angka kejadian gastritis di Kota Surabaya telah mencapai 31,2persen ${ }^{3} \mathrm{Hal}$ ini menunjukkan bahwa permasalahan gastritis di masyarakat cukup tinggi dan perlu mendapatkan perhatian.

Salah satu faktor pemicu gastritis adalah konsumsi tinggi protein dalam menu harian. Hal ini dikarenakan pola makan tinggi protein dapat memicu tingginya sekresi asam lambung. Faktor asam lambung sangat berperan pada penyakit gastritis. Penyakit ini timbul akibat ketidakseimbangan asam lambung sebagai faktor agresif dan mukosa lambung sebagai faktor protektif. Faktor agresif lebih dominan sehingga mengakibatkan terjadinya iritasi mukosa pada dinding lambung. Dengan demikian konsumsi makanan dan minuman yang memicu tingginya sekresi asam lambung adalah penyebab penting terjadinya gastritis. Selain konsumsi tinggi protein, kebiasaan mengkonsumsi makanan pedas dan minum kopi juga dapat memicu terjadinya gastristis. Hal ini disebabkan makanan pedas bersifat merangsang organ pencernaan dan dapat menimbulkan iritasi pada lapisan mukosa lambung, sedangkan kandungan kafein pada kopi dapat meningkatkan aktivitas produksi asam lambung. Produksi asam lambung berlebihan inilah yang dapat mengakibatkan terjadinya gastritis karena peradangan pada dinding lambung.

Beberapa penelitian terkait penyakit gastritis yang telah dilakukan diantaranya penelitian tentang faktor yang berhubungan dengan penyakit gastritis seperti kebiasaan makan, tingkat stress, usia, tingkat pengetahuan, dan kebiasaan merokok 2, penelitian tentang infeksi helicobacter pylori pada kejadian gastritis 4 , penelitian tentang kebiasaan minum kopi dan kejadiaan gastritis. ${ }^{5}$ Penelitian terkait pola makan khususnya pola konsumsi menu tinggi protein masih jarang ditemui. Berdasarkan hal tersebut juga tingginya angka gastritis di Surabaya, peneliti tertarik untuk menganalisis apakah riwayat pola konsumsi protein, sambal dan kebiasaan minum kopi merupakan faktor risiko terjadinya kasus gastritis melalui studi observasional pada penderita gastritis di Rumah Sakit Islam (RSI) Surabaya. Tujuan dari penelitian ini adalah menganalisis estimasi faktor risiko berupa riwayat konsumsi makanan yang meningkatkan kandungan asam lambung terhadap kejadian gastritis di RSI Surabaya.

\section{METODE PENELITIAN}

Penelitian ini merupakan penelitian observasional analitik dengan desain case control. Lokasi penelitian di RSI Surabaya. Populasi dalam penelitian ini meliputi populasi kasus yaitu seluruh pasien dengan diagnosis gastritis di instalasi rawat jalan maupun rawat inap pada periode Juli 2012 dan populasi kontrol yaitu pasien non-gastritis maupun keluarga pasien gastritis pada periode Juli 2012 dengan catatan tidak sedang menderita gastritis maupun penyakit berat lain. Besar sampel adalah 32 orang, terdiri dari 16 orang kelompok kasus dan 16 orang kelompok kontrol. Pengambilan sampel dilakukan dengan cara Systematic random sampling.

Variabel terikat pada penelitian ini adalah kejadian gastritis pada pasien di RSI Surabaya, sedangkan variabel bebas meliputi riwayat pola konsumsi protein, riwayat pola konsumsi sambal, dan riwayat kebiasaan minum kopi. Data diperoleh melalui wawancara menggunakan Form Dietary History dan Food Frequency semi quantitative, dan data sekunder dari RSI Surabaya mengenai riwayat penyakit gastritis pada pasien. Teknik analisis data yang digunakan adalah perhitungan faktor risiko dengan metode Case control untuk mengetahui OR (Odd Ratio) kasus, serta uji Chi-square untuk mengetahui tingkat signifikansi. 
Tabel 1

Distribusi Karakteristik Responden Gastritis dan Non Gastritis di RSI Surabaya

\begin{tabular}{lcccc}
\hline \multirow{2}{*}{ Variabel } & \multicolumn{2}{c}{ Gastritis } & \multicolumn{2}{c}{ Non Gastritis } \\
\cline { 2 - 5 } & $\mathrm{n}$ & $\%$ & $\mathrm{n}$ & $\%$ \\
\hline Jenis Kelamin: & 2 & 12,50 & 5 & 31,25 \\
$\quad$ Laki-laki & 2 & 87,50 & 11 & 68,75 \\
$\quad$ Perempuan & 14 & & & \\
Kelompok Usia & & & 5 & 31,25 \\
20-30 tahun & 8 & 50,00 & 6 & 37,50 \\
31-50 tahun & 6 & 37,50 & 5 & 31,25 \\
51-60 tahun & 2 & 12,50 & & \\
Lama menderita gastritis & & & & - \\
$<1$ bulan & 1 & 6,25 & - & - \\
1-3 bulan & 3 & 18,75 & - & - \\
3-12 bulan & 0 & 0,00 & - & - \\
1-3 tahun & 5 & 31,25 & - & - \\
$>3$ tahun & 7 & 43,75 & - & \\
\hline
\end{tabular}

HASIL

Karakteristik responden dalam penelitian ini dapat dilihat pada Tabel 1. Berdasarkan jenis kelamin, sebagian besar responden adalah perempuan baik pada kelompok gastritis maupun nongastritis. Usia sebagian besar responden pada kelompok gastritis adalah 20 30 tahun, sedangkan responden non-gastritis adalah 31-50 tahun. Pada responden gastritis sebagian besar telah mengalami gastritis $>3$ tahun $(43,75 \%)$. Melalui instrument Dietary history dan food frequency semi quantitative didapatkan riwayat konsumsi makanan responden (Tabel 2).

Tabel 2 menunjukkan sebagian besar responden gastritis memiliki riwayat frekuensi konsumsi susu sering sebesar 68,75persen Konsumsi susu sering yang dimaksud adalah konsumsi susu dalam jangka waktu mingguan hingga harian. Frekuensi konsumsi protein hewani jenis lain pada responden gastritis juga cenderung lebih tinggi dibanding responden non-gastritis, kecuali frekuensi konsumsi daging ayam dan ikan sama besar baik pada kelompok responden gastritis maupun non-gastritis.
Menurut jumlah konsumsinya, tingkat konsumsi protein hewani pada kedua kelompok baik gastritis maupun non-gastritis cukup tinggi.

Seperti pada konsumsi susu, responden yang memiliki riwayat konsumsi susu 1 sampai $1 \frac{1}{2}$ gelas untuk tiap konsumsi pada responden gastritis sebanyak 75 persen sedangkan pada responden non-gastritis sebanyak 81,25 persen Jumlah konsumsi protein hewani tertinggi terdapat pada konsumsi ikan, yakni sebesar 93,75 pada responden gastritis dan $81,25 \%$ pada responden non-gastritis. Pada variabel frekuensi konsumsi minum kopi, sebagian besar responden gastritis memiliki riwayat minum kopi yang sering yakni sebesar 75persen sedangkan responden non-gastritis sebanyak 93,75persenmemiliki riwayat kebiasaan minum kopi yang jarang. Responden gastritis sebagian besar juga memiliki riwayat frekuensi konsumsi sambal terkategori sering yaitu sebesar 81,25 persen Pada kelompok non-gastritis riwayat jumlah konsumsi sambal mayoritas responden adalah < 3 sdt untuk tiap konsumsi. Berdasarkan data yang diperoleh dilakukan uji statistik untuk mendapatkan nilai estimasi risiko masing-masing variabel penelitian. 
Tabel 2

Distribusi Riwayat Konsumsi Makanan Responden

\begin{tabular}{|c|c|c|c|c|}
\hline \multirow{2}{*}{ Variabel } & \multicolumn{2}{|c|}{ Gastritis } & \multicolumn{2}{|c|}{ Non Gastritis } \\
\hline & $n$ & $\%$ & $\mathrm{n}$ & $\%$ \\
\hline \multicolumn{5}{|l|}{ Riwayat Konsumsi Protein : } \\
\hline \multicolumn{5}{|l|}{ Frekuensi konsumsi susu: } \\
\hline Tidak pernah-bulanan & 5 & 31,25 & 12 & 75,00 \\
\hline Mingguan-harian & 11 & 68,75 & 4 & 25,00 \\
\hline \multicolumn{5}{|l|}{ Jumlah konsumsi susu : } \\
\hline$<1$ gelas & 2 & 12,50 & 5 & 31,25 \\
\hline $1-1 / 2$ gelas & 14 & 87,50 & 11 & 68,75 \\
\hline \multicolumn{5}{|l|}{ Frekuensi konsumsi daging ayam : } \\
\hline Tidak pernah-bulanan & 4 & 25,00 & 3 & 18,75 \\
\hline Mingguan-harian & 12 & 75,00 & 13 & 81,25 \\
\hline \multicolumn{5}{|l|}{ Jumlah konsumsi daging ayam : } \\
\hline$<1$ potong & 4 & 25,00 & 5 & 31,25 \\
\hline $1-3$ potong & 12 & 75,00 & 11 & 68,75 \\
\hline \multicolumn{5}{|l|}{ Frekuensi konsumsi daging sapi : } \\
\hline Tidak pernah-bulanan & 3 & 18,75 & 5 & 31,25 \\
\hline Mingguan-harian & 13 & 81,25 & 11 & 68,75 \\
\hline \multicolumn{5}{|l|}{ Jumlah konsumsi daging sapi : } \\
\hline$<1$ potong & 2 & 12,50 & 6 & 37,50 \\
\hline $1-3$ potong & 14 & 87,50 & 10 & 62,50 \\
\hline \multicolumn{5}{|l|}{ Frekuensi konsumsi ikan : } \\
\hline Tidak pernah-bulanan & 4 & 25,00 & 3 & 18,75 \\
\hline Mingguan-harian & 12 & 75,00 & 13 & 81,25 \\
\hline \multicolumn{5}{|l|}{ Jumlah konsumsi daging ikan : } \\
\hline$<1$ potong & 1 & 06,25 & 3 & 18,75 \\
\hline $1-3$ potong & 15 & 93,75 & 13 & 81,25 \\
\hline \multicolumn{5}{|l|}{ Frekuensi konsumsi telur: } \\
\hline Tidak pernah-bulanan & 1 & 06,25 & 5 & 31,25 \\
\hline Mingguan-harian & 15 & 93,75 & 11 & 68,75 \\
\hline \multicolumn{5}{|l|}{ Jumlah konsumsi telur : } \\
\hline 1 butir & 12 & 75,00 & 15 & 93,75 \\
\hline 2 butir & 4 & 25,00 & 1 & 6,25 \\
\hline \multicolumn{5}{|l|}{ Jumlah jenis konsumsi protein hewani } \\
\hline $0-1$ jenis & 7 & 43,75 & 12 & 75,00 \\
\hline$\geq 2$ jenis & 9 & 56,25 & 4 & 25,00 \\
\hline \multicolumn{5}{|l|}{ Jumlah jenis konsumsi protein nabati } \\
\hline $0-1$ jenis & 6 & 37,50 & 8 & 50,00 \\
\hline$\geq 2$ jenis & 10 & 62,50 & 8 & 50,00 \\
\hline \multicolumn{5}{|l|}{ Riwayat kebiasaan minum kopi } \\
\hline \multicolumn{5}{|l|}{ Frekuensi konsumsi minum kopi : } \\
\hline Tidak pernah-2 s/d 4 cangkir perminggu & 12 & 75,00 & 15 & 93,75 \\
\hline$\geq 5$ s/d 6 cangkir perminggu & 4 & 25,00 & 1 & 6,25 \\
\hline \multicolumn{5}{|l|}{ Riwayat konsumsi sambal: } \\
\hline \multicolumn{5}{|l|}{ Frekuensi konsumsi sambal: } \\
\hline Tidak pernah-mingguan & 3 & 18,75 & 9 & 56,25 \\
\hline Harian & 13 & 81,25 & 7 & 43,75 \\
\hline \multicolumn{5}{|l|}{ Jumlah konsumsi sambal : } \\
\hline$\leq 3 \mathrm{sdt}$ & 9 & 56,25 & 15 & 93,75 \\
\hline$>3 \mathrm{sdt}$ & 7 & 43,75 & 1 & 6,25 \\
\hline
\end{tabular}


Tabel 3

Estimasi Risiko Seluruh Variabel

\begin{tabular}{|c|c|c|c|c|}
\hline Variabel bebas & OR & $p$ & $\alpha$ & Keterangan \\
\hline Frekuensi konsumsi susu & 6,600 & 0,034 & 0,05 & $\begin{array}{l}\text { Kelompok kasus lebih berisiko 6,6 kali } \\
\text { untuk menderita gastritis dibanding } \\
\text { kelompok kontrol }\end{array}$ \\
\hline Jumlah konsumsi susu & 3,182 & 0,394 & 0,05 & $\begin{array}{l}\text { Risiko kelompok kasus dan kontrol sama } \\
\text { besar (OR dianggap 1) }\end{array}$ \\
\hline $\begin{array}{l}\text { Frekuensi konsumsi daging } \\
\text { ayam }\end{array}$ & 0,692 & 1,000 & 0,05 & Bukan faktor risiko gastritis \\
\hline $\begin{array}{l}\text { Jumlah konsumsi daging } \\
\text { ayam }\end{array}$ & 1,364 & 1,000 & 0,05 & $\begin{array}{l}\text { Risiko kelompok kasus dan kontrol sama } \\
\text { besar (OR dianggap 1) }\end{array}$ \\
\hline $\begin{array}{l}\text { Frekuensi konsumsi daging } \\
\text { sapi }\end{array}$ & 1,970 & 0,685 & 0,05 & $\begin{array}{l}\text { Risiko kelompok kasus dan kontrol sama } \\
\text { besar (OR dianggap 1) }\end{array}$ \\
\hline Jumlah konsumsi daging sapi & 4,200 & 0,220 & 0,05 & $\begin{array}{l}\text { Risiko kelompok kasus dan kontrol sama } \\
\text { besar (OR dianggap 1) }\end{array}$ \\
\hline Frekuensi konsumsi ikan & 0,692 & 1,000 & 0,05 & Bukan faktor risiko gastritis \\
\hline Jumlah konsumsi ikan & 3,462 & 1,600 & 0,05 & $\begin{array}{l}\text { Risiko kelompok kasus dan kontrol sama } \\
\text { besar (OR dianggap 1) }\end{array}$ \\
\hline Frekuensi konsumsi telur & 6,818 & 0,172 & 0,05 & $\begin{array}{l}\text { Risiko kelompok kasus dan kontrol sama } \\
\text { besar (OR dianggap 1) }\end{array}$ \\
\hline Jumlah konsumsi telur & 5,000 & 0,333 & 0,05 & $\begin{array}{l}\text { Risiko kelompok kasus dan kontrol sama } \\
\text { besar (OR dianggap 1) }\end{array}$ \\
\hline $\begin{array}{l}\text { Jumlah jenis konsumsi protein } \\
\text { hewani }\end{array}$ & 3,857 & 0,150 & 0,05 & $\begin{array}{l}\text { Risiko kelompok kasus dan kontrol sama } \\
\text { besar (OR dianggap 1) }\end{array}$ \\
\hline $\begin{array}{l}\text { Jumlah jenis konsumsi protein } \\
\text { nabati }\end{array}$ & 1,667 & 0,722 & 0,05 & $\begin{array}{l}\text { Risiko kelompok kasus dan kontrol sama } \\
\text { besar (OR dianggap 1) }\end{array}$ \\
\hline Frekuensi konsumsi kopi & 5,000 & 0,333 & 0,05 & $\begin{array}{l}\text { Risiko kelompok kasus dan kontrol sama } \\
\text { besar (OR dianggap 1) }\end{array}$ \\
\hline Frekuensi konsumsi sambal & 5,571 & 0,068 & 0,05 & $\begin{array}{l}\text { Risiko kelompok kasus dan kontrol sama } \\
\text { besar (OR dianggap 1) }\end{array}$ \\
\hline Jumlah konsumsi sambal & 11,667 & 0,037 & 0,05 & $\begin{array}{l}\text { Kelompok kasus lebih berisiko 11,667 kali } \\
\text { untuk menderita gastritis dibanding } \\
\text { kelompok kontrol. }\end{array}$ \\
\hline
\end{tabular}

\section{BAHASAN}

\section{Karakteristik Responden}

Pada hasil penelitian tampak bahwa mayoritas responden gastritis berjenis kelamin perempuan. Perempuan mungkin lebih mudah menderita gastritis dibandingkan pria dikarenakan tingkat kejadian stress pada perempuan cenderung lebih tinggi dibanding pada laki-laki, sebagaimana kajian psikologi yang menyebutkan jumlah perempuan yang mengalami depresi dua kali lebih banyak dibandingkan laki-laki. ${ }^{6}$ Hasil penelitian juga menunjukkan kejadian gastritis banyak ditemukan pada pasien usia produktif pada rentang 20-50 tahun. Pada rentang usia produktif ini pola makan seseorang cenderung lebih dipengaruhi oleh lingkungannya karena sebagian besar aktifitas dilakukan di luar rumah. Tak jarang karena tuntutan kesibukannya seseorang menjadi cendurung melalaikan atau menunda-nunda jam makan. ${ }^{7}$ Berdasarkan lama menderita gastritis, sebagian besar responden telah mengalami gastritis lebih dari tiga tahun. Hal ini menunjukkan bahwa sebagian besar responden mengalami gastritis kronis. Kejadian gastritis kronis adalah hasil dari pola makan dan gaya hidup yang tidak sehat secara terus menerus sehingga mengakibatkan perubahan pada sel epitel mukosa lambung. ${ }^{8}$ 


\section{Estimasi Risiko \\ Frekuensi konsumsi susu}

Hasil uji estimasi risiko menunjukkan bahwa responden penelitian yang mengalami gastritis sebagian besar adalah responden yang memiliki riwayat kebiasaan konsumsi susu sering, yakni frekuensi konsumsi susu mingguan hingga harian. Risiko gastritis lebih besar pada responden yang memiliki kebiasaan konsumsi susu sering, bukan berarti menyatakan bahwa kebiasaan konsumsi susu merupakan hal berbahaya yang harus dihindari. Susu merupakan minuman bergizi yang baik untuk memenuhi kebutuhan nutrisi harian masyarakat, terutama karena kandungan protein, lemak, vitamin dan mineral yang terdapat pada susu cukup memadai dan lengkap. Namun hal yang perlu diperhatikan adalah pola konsumsi susu tersebut. Susu memiliki kandungan protein yang cukup tinggi dan memerlukan proses pencernaan yang lebih rumit. Kadar kasein (bentuk protein yang kental dan kasar) pada susu sapi 300 persen lebih tinggi dari pada kadar kasein pada ASI. Selain itu pencernaan kasein susu membutuhkan bantuan enzim khusus yaitu enzim renin yang hanya dihasilkan pada usia bayi muda, sedangkan pada usia dewasa pencernaan susu hanya dibantu oleh enzim pepsin yaitu enzim pencernaan protein umum, sehingga prosesnya menjadi lebih berat. ${ }^{9}$ Kandungan protein yang tinggi pada susu tersebut menyebabkan minuman bergizi ini sebaiknya tidak dikonsumsi bersamaan dengan makan utama atau makanan berat lain yang juga berprotein tinggi, sebab hal tersebut akan memicu produksi asam lambung berlebihan yang diperlukan untuk mencerna setiap molekul protein. Produksi asam lambung berlebihan akan menyebabkan suasana pada lambung menjadi sangat asam sehingga rentan terjadi iritasi atau perlukaan pada mukosa lambung. ${ }^{10}$

\section{Jumlah konsumsi susu}

Ukuran jumlah konsumsi susu pada responden berdasarkan URT yaitu satu gelas susu sama dengan 200 gram. Hasil penelitian menunjukkan mayoritas responden pada kelompok gasritis maupun non-gastritis memiliki riwayat kebiasaan jumlah konsumsi susu sekitar 1- $1 \frac{1}{2}$ gelas per konsumsi. Berdasarkan hasil penelitian, jumlah konsumsi susu bukanlah faktor risiko kejadian gastritis pada responden.
Namun demikian untuk menjaga kesehatan pencernaan tetap perlu diperhatikan bahwa waktu konsumsi susu yang baik adalah dilakukan tidak bersamaan jam makan utama atau tidak bersamaan dengan konsumsi makanan berat lainnya, semisal makanan lain yang juga tinggi kandungan protein, karbohidrat, atau lemak. Sebab konsumsi dua makanan berat, seperti susu dan nasi rendang, hanya akan memperberat kerja lambung dan menyebabkan suasana asam yang berlebihan pada lambung. Selain dapat mengikis lapisan mukosa lambung, suasana asam yang berlebihan juga mengganggu pencernaan kalsium yang diperoleh dari susu karena kalsium akan hancur dalam keasaman tinggi. ${ }^{9}$

\section{Frekuensi konsumsi daging ayam}

Pada variabel frekuensi konsumsi daging ayam, berdasarkan hasil penelitian dapat diketahui sebagian besar responden memiliki riwayat kebiasaan frekuensi konsumsi daging ayam sering, yakni konsumsi daging ayam dengan frekuensi harian hingga mingguan. Hasil penelitian menunjukkan bahwa sebagian besar responden baik responden gastritis maupun non-gastritis memiliki kebiasaan konsumsi daging ayam terkategori sering, sehingga berdasarkan perhitungan OR pada hasil penetian, konsumsi daging ayam bukan merupakan bagian dari faktor risiko kejadian gastritis.

\section{Jumlah konsumsi daging ayam}

Peneliti menetapkan ukuran jumlah konsumsi daging ayam pada responden berdasarkan URT yaitu satu potong daging ayam sama dengan 40 gram. Pada sepotong daging ayam dengan ukuran 40 gram tersebut terkandung sekitar 12,20 gram protein. Jumlah konsumsi tersebut telah memenuhi sekitar 20,33persen kebutuhan protein harian pada laki-laki dewasa berdasarkan angka kecukupan gizi. Kandungan protein pada daging ayam cukup tinggi, oleh sebab itu pada saat mengkonsumsi daging ayam perlu diperhatikan pula makanan pendamping lain yang disajikan. Akan lebih baik apabila menu daging ayam disajikan bersama dengan sayuran, sebab sayuran kaya akan mineral yang bersifat basa dalam tubuh sehingga dapat mengimbangi sifat asam yang dihasilkan dari pencernaan daging ayam. ${ }^{9}$ Kesalahan yang sering terjadi adalah 
menu daging ayam seringkali disajikan dengan menu berat lainya misalnya telur, daging sapi, atau hati sementara tidak disertakan sayuran sebagai penyeimbang asam-basa, sehingga kondisi keasaman lambung pun semakin meningkat.

\section{Frekuensi konsumsi daging sapi}

Berdasarkan hasil penelitian diketahui bahwa sebagian besar responden baik kelompok gastritis dan non-gastritis memiliki kebiasaan konsumsi daging sapi yang sering, yakni harian hingga mingguan. Walaupun tidak menunjukkan hubungan yang signifikan dengan kejadian gastritis, frekuensi konsumsi daging sapi sebaiknya tidak berlebihan. Daging sapi memiliki kandungan protein tinggi yang penting untuk proses pertumbuhan dan mikronutrien terutama zat besi yang dibutuhkan oleh tubuh untuk pembentukan sel darah merah. Namun demikian frekuensi konsumsi daging sapi yang terlalu sering juga akan mempercepat proses penuaan. ${ }^{11}$ Disamping itu, kebiasaan konsumsi daging sapi dengan frekuensi rutin perlu dirubah sebab kandungan lemak jenuh yang tinggi pada daging sapi dapat meningkatkan kadar kolesterol LDL yang mengakibatkan penyumbatan pembuluh darah korener jantung sehingga meningkatkan risiko terjadinya serangan jantung. Sebuah studi telah dilakukan terhadap 500.000 orang Amerika pada usia pertengahan. Hasil studi menunjukkan mereka yang mengonsumsi sekitar 4 ons daging sapi setiap hari, lebih dari 30 persen diantaranya meninggal akibat penyakit jantung dan kanker setelah sekitar 10 tahun mereka diikuti dalam studi tersebut. ${ }^{12}$

\section{Jumlah konsumsi daging sapi}

Pada variabel jumlah konsumsi daging sapi, peneliti menetapkan ukuran jumlah konsumsi daging sapi pada responden berdasarkan URT yaitu satu potong daging sapi sama dengan 60 gram. Pada sepotong daging sapi dengan ukuran 60 gram tersebut terkandung sekitar 11,28 gram protein. Jumlah konsumsi tersebut telah memenuhi sekitar 18,80persen kebutuhan protein harian pada lakilaki dewasa berdasarkan angka kecukupan gizi. Hasil penelitian menunjukkan bahwa responden penelitian yang mengalami gastritis sebagian besar adalah responden yang memiliki riwayat kebiasaan konsumsi daging sapi dengan jumlah konsumsi sekitar 1-3 potong per konsumsi, namun dari hasil uji statistik menunjukkan variabel jumlah konsumsi daging sapi ini tidak bernilai signifikan dengan kejadian gastritis. Meskipun demikian, konsumsi daging sapi yang berlebihan sebaiknya dihindari terutama apabila berdampingan dengan menu berat lainnya. Pencernaan daging sapi membutuhkan suasana asam lambung yang pekat karena daging sapi mengandung jaringan ikat kolagen yang sulit dicerna. Dengan bantuan asam lambung tersebutlah jaringan kolagen tersebut dapat dilumatkan. ${ }^{13}$ Produksi asam lambung yang tinggi untuk pencernaan daging sapi tersebut dapat lebih berisiko terjadinya iritasi pada mukosa lambung apabila didukung dengan konsumsi daging sapi yang berlebihan atau kombinasi makanan berprotein tinggi lainnya terlebih apabila dengan bumbu yang terlalu tajam.

\section{Frekuensi konsumsi ikan}

Berdasarkan hasil penelitian diketahui bahwa sebanyak 78,13 persenresponden memiliki kebiasaan konsumsi ikan sering, yakni harian hingga mingguan. Hal ini menunjukkan bahwa tingkat konsumsi ikan pada responden yang berkunjung ke RSI Surabaya cukup baik. Hasil penelitian menunjukkan bahwa responden kelompok gastritis maupun non-gastritis mayoritas memiliki kebiasaan konsumsi ikan sering, sehingga berdasarkan probabilitas dan perhitungan OR pada hasil penelitian, konsumsi ikan bukan merupakan bagian dari faktor risiko kejadian gastritis.

\section{Jumlah konsumsi ikan}

Pada variabel jumlah konsumsi daging, peneliti menetapkan ukuran jumlah konsumsi ikan yaitu setara ikan bandeng dengan berat 50 gram per potong. Peneliti memilih ikan bandeng karena ikan ini merupakan salah satu jenis ikan yang paling banyak dikonsumsi oleh masyarakat kota Surabaya. ${ }^{14}$ Pada sepotong ikan bandeng dengan ukuran 50 gram tersebut terkandung sekitar 10 gram protein. Jumlah tersebut telah memenuhi sekitar 16,67persenkebutuhan protein harian pada lakilaki dewasa berdasarkan angka kecukupan gizi. Hasil penelitian menunjukkan bahwa responden penelitian yang mengalami gastritis sebagian besar adalah responden yang memiliki riwayat kebiasaan konsumsi ikan dengan jumlah 
konsumsi sekitar 1-3 potong per konsumsi, namun hasil uji statistik belum menunjukkan bahwa konsumsi daging ikan merupakan faktor yang berpengaruh terhadap kejadian gastritis pada responden.

\section{Frekuensi konsumsi telur}

Berdasarkan hasil penelitian diketahui bahwa sebagian besar responden kelompok gastritis dan non-gastritis memiliki kebiasaan konsumsi telur terkategori sering, yakni harian hingga mingguan. Hal ini menunjukkan bahwa tingkat konsumsi telur pada responden cukup baik. Namun berdasarkan hasil uji statistik didapatkan bahwa risiko pada kelompok responden yang memiliki riwayat konsumsi telur sering maupun jarang adalah sama besar. Hasil penelitian yang tidak signifikan juga memungkinkan adanya faktor lain yang mempengaruhi tingginya risiko gastritis pada responden yang memiliki riwayat konsumsi telur sering. Faktor lain itu seperti jumlah telur dalam menu untuk sekali konsumsi, makanan pendamping lainnya, maupun ketajaman bumbu yang digunakan dalam memasak menu.

\section{Jumlah konsumsi telur}

Jumlah konsumsi telur pada responden berdasarkan URT adalah satu butir telur ayam negeri rebus sama dengan 59 gram. Pada sebutir telur ayam negeri rebus dengan ukuran 59 gram tersebut terkandung sekitar 12,80 gram protein. Jumlah konsumsi tersebut telah memenuhi sekitar 21,33persen kebutuhan protein harian pada laki-laki dewasa berdasarkan angka kecukupan gizi. Hasil penelitian menunjukkan bahwa responden penelitian yang memiliki riwayat konsumsi telur 2 butir per konsumsi sebagian besar mengalami gastritis. Telur merupakan protein hewani berbentuk kapsul alami yang kaya akan kandungan gizi. Kandungan asam amino pada telur sangat lengkap sehingga protein pada telur menjadi protein referensi yang istilah gizi disebut protein senilai telur (PST). Telur juga mengandung vitamin $B$ kompleks, vitamin $A$ dan Vitamin $D$, serta kaya akan kandungan fosfor dan zat besi. Disamping itu, kandungan kolesterol pada telur juga sangat tinggi. Satu butir telur per hari telah mencukupi sekitar 80persen dari kebutuhan kolesterol tubuh. Oleh sebab itu, konsumsi telur sebaiknya juga tidak berlebihan. ${ }^{15}$

\section{Jumlah jenis konsumsi protein hewani}

Jumlah jenis konsumsi protein hewani menjelaskan kuantitas atau jumlah jenis protein hewani yang dikonsumsi oleh responden untuk sekali konsumsi berdasarkan riwayat kebiasaan konsumsi dan kaitannya dengan kejadian gastritis. Protein hewani yang dimaksud dapat berupa telur, daging ayam, daging sapi, atau ikan. Hasil penelitian menunjukkan bahwa responden penelitian yang memiliki riwayat konsumsi protein hewani sebanyak 2 jenis atau lebih untuk setiap konsumsi sebagian besar mengalami kejadian gastritis, sehingga probabilitas kejadian gastritis pada responden yang memiliki riwayat kebiasaan konsumsi protein hewani sebanyak 2 jenis atau lebih per konsumsi lebih besar daripada probabilitas responden yang memiliki riwayat kebiasaan konsumsi 0-1 jenis protein hewani saja untuk tiap konsumsi. Konsumsi protein hewani lebih dari satu jenis sekaligus dalam satu menu dapat memberatkan pencernaan. Hal ini dikarenakan makanan yang mengandung protein hewani pada umumnya juga mengandung lemak. Protein dan lemak yang berlebihan dalam lambung akan memperlambat proses pencernaan, sehingga makanan dapat membusuk dalam tubuh dan penyerapan gizi menjadi tidak sempurna. Proses pencernaan yang berat juga akan menyita banyak energi dari tubuh hingga pada gilirannya badan akan merasa lemas, lesu, dan mudah mengantuk. Disamping itu kelebihan konsumsi protein hewani juga meningkatkan risiko gastritis karena dapat mengakibatkan kondisi lambung menjadi semakin asam. ${ }^{13}$

\section{Jumlah jenis konsumsi protein nabati}

Jumlah jenis konsumsi protein nabati menjelaskan kuantitas atau jumlah jenis protein nabati yang dikonsumsi oleh responden untuk sekali konsumsi berdasarkan riwayat kebiasaan konsumsi dan kaitannya dengan kejadian gastritis. Protein nabati yang dimaksud dapat berupa tahu, tempe, oncom, kacang hijau, dan sebagainya. Hasil uji statistik menunjukkan bahwa jumlah jenis konsumsi protein nabati bukanlah faktor yang berpengaruh terhadap kejadian gastritis. Berbeda dengan protein hewani, kombinasi konsumsi protein nabati disarankan oleh beberapa ahli. Kandungan asam amino pada protein nabati cenderung tidak lengkap. Kekurangan tersebut dapat 
diperbaiki dengan mengkombinasikan beberapa jenis protein nabati untuk saling mendukung seperti mengkombinasikan nasi merah dengan tempe, nasi dengan tahu atau perkedel kacang merah, atau sup dengan isi aneka biji-bijian dan polong-polongan. Kandungan lemak pada protein nabati pun cukup rendah sehingga proses pencernaannya tidak seberat pencernaan protein hewani. ${ }^{9}$

\section{Frekuensi minum kopi}

Berdasarkan hasil penelitian diketahui bahwa hanya 25persen responden gastritis yang memiliki kebiasaan konsumsi kopi sering, yakni 5-6 kali perminggu atau lebih. Hasil uji statistik belum menunjukkan bahwa konsumsi kopi merupakan faktor yang berpengaruh terhadap kejadian gastritis pada responden. Hal tersebut mungkin dikarenakan adanya pengaruh bias penelitian ataupun faktor lain yang mungkin mempengaruhi semisal waktu konsumsi kopi, tingkat kekentalan kopi, apakah tiap cangkir kopi yang disajikan dihabiskan oleh responden, dan sebagainya. Disamping minuman yang bersifat asam karena mengandung beberapa jenis senyawa asam diantaranya malic acid, tannic acid, maleic acid, oleic acid, oxalic acid, caffeic acid, dan chlorogenic acid, kandungan kafein pada kopi juga dapat menstimulasi sistem saraf pusat sehingga meningkatkan aktivitas lambung untuk sekresi asam lambung dan pepsin. ${ }^{16}$ Dengan demikian suasana lambung akan menjadi semakin asam yang mengakibatkan mukosa lambung rentan mengalami iritasi. Beberapa penelitian menunjukkan adanya hubungan antara konsumsi kopi dan kejadian gastritis ${ }^{17}$ dan risiko kanker lambung pada 61,433 wanita di negara Swedia menunjukkan hasil bahwa penambahan satu cangkir kopi perhari berhubungan signifikan dengan risiko peningkatan kanker lambung sebesar 22persen Perlu diperhatikan disini kejadian kanker lambung sering bermula dari gastritis yang tidak segera ditangani. ${ }^{13}$

\section{Frekuensi konsumsi sambal}

Frekuensi konsumsi sambal responden menjelaskan seberapa sering riwayat konsumsi sambal pada responden sebagai suatu kebiasaan dan kaitannya dengan kejadian gastritis. Berdasarkan hasil penelitian diketahui bahwa sebagian besar responden gastritis
$(81,25 \%)$ memiliki kebiasaan konsumsi sambal sering yakni harian. Berdasarkan hasil uji statistik frekuensi konsumsi sambal bukanlah faktor yang berpengaruh terhadap kejadian gastritis pada resonden. Hal ini berbeda dengan studi luas yang dilakukan di China pada tahun 2009-2011 yang melibatkan 1024 responden. Hasil studi tersebut menyatakan bahwa konsumsi makanan pedas secara rutin merupakan salah satu faktor risiko terjadinya Precancerous Lesion of Gastric Cancer (PLGC) yakni timbulnya luka pada lambung yang dapat mengarah pada terjadinya kanker. ${ }^{18}$ Secara medis timbulnya luka tersebut dikarenakan iritasi akibat produksi asam lambung berlebih yang distimulasi oleh makanan pedas. ${ }^{19}$

\section{Jumlah konsumsi sambal}

Pada variabel jumlah konsumsi sambal, peneliti menetapkan ukuran jumlah konsumsi sambal pada responden berdasarkan URT yaitu satu sendok teh sambal sama dengan 5 gram. Hasil penelitian menunjukkan bahwa responden penelitian yang memiliki riwayat kebiasaan konsumsi sambal 3 sendok teh atau lebih per konsumsi sebagian besar mengalami gastritis. Hasil uji statistik menunjukkan nilai yang signifikan $(p=0,037, O R=11,667)$, dengan demikian risiko kejadian gastritis pada responden yang memiliki riwayat kebiasaan konsumsi sambal dengan jumlah konsumsi 3 sendok teh atau lebih per konsumsinya pun 11,667 kali lebih besar daripada responden yang memiliki riwayat kebiasaan konsumsi sambal dengan jumlah konsumsi kurang dari 3 sendok teh per konsumsi. Rasa pedas pada sambal sebenarnya merupakan kombinasi dari beberapa asam, disamping itu juga merupakan salah satu bahan makanan yang dapat meningkatkan produksi asam lambung sehingga suasana asam pada lambung dapat menjadi semakin tinggi. Susana asam yang tinggi ini dapat menjadi faktor agresif yang dapat menyerang dinding lambung dan menyebabkan perlukaan pada mukosa lambung. ${ }^{20}$

\section{SIMPULAN DAN SARAN}

\section{Simpulan}

Jenis kelamin responden mayoritas adalah perempuan baik pada kelompok gastritis maupun non-gastritis. Menurut penggolongan 
usia, mayoritas responden pada kedua kelompok berada pada rentang usia produktif, dan pada kelompok responden gastritis sebagian besar diantaranya telah menderita gastritis lebih dari 3 tahun. Pola konsumsi yang merupakan faktor risiko kejadian gastritis pada pasien gastritis di RSI Surabaya adalah frekuensi konsumsi susu sering (mingguanharian) dan jumlah konsumsi sambal lebih dari 3 sendok teh per konsumsi. Frekuensi konsumsi susu sering mungkin terkait dengan waktu konsumsi susu responden yang bersamaan dengan jam makan utama atau makanan berat lainnya.

\section{Saran}

Masyarakat baik yang penderita gastritis maupun bukan penderita gastritis sebaiknya membatasi konsumsi susu yang bersamaan dengan jam makan utama serta membatasi konsumsi sambal yang berlebihan (sebaiknya kurang dari 3 sendok teh), karena kedua hal tersebut dapat meningkatkan risiko terjadinya gastritis.

\section{RUJUKAN}

1. Ansari M, Omrani M, Sayyah B, Ansari S. Effect of Helicobacter Pylori Infection on the Lipid, Lipoproteins, Apolipoprotein-A1, Lipoprotein $A$ and Apolipoprotein-B in Patients with Gastritis. African Journal of Microbiology Research. 2009;4(1):84-87.

2. Gustin R. Faktor-Faktor Yang Berhubungan Dengan Kejadian Gastritis Pada Pasien Yang Berobat Jalan di Puskesmas Gulai Bancah Kota Bukittinggi. Laporan Penelitian. Padang: Fakultas Kedokteran UNAND, 2011.

3. Siregar S, Siagian A. Gambaran Pola Makan Penderita Gastritis di Wilayah Kerja Puskesmas Kampar Kiri Hulu Kecamatan Kampar Kiri Hulu Kabupaten Kampar Riau Tahun 2012. Jurnal Gizi Kesehatan Reproduksi dan Epidemiologi.2012;1(2): 612.

4. Egan B, Holmes K, O'Connor H, O'Morain C. Helicobacter pylori Gastritis, the Unifying Concept for Gastric Diseases. Helicobacter 2007;12(Supplemen2):39-44.

5. Fatmawati $W$, Surya $M$, Wahyuni $T$, Bramastha, Wibowo A, Agung R, et al. Hubungan Kebiasaan Merokok dan Minum
Kopi dengan Kejadian Gastritis di Dusun Turi, Desa Turirejo, Kecamatan Lawang, Kabupaten Malang. Laporan Penelitian. Surabaya; Fakultas Kedokteran UNAIR, 2006.

6. Davison GC, Neale JM, Kring AM. Psikologi Abnormal. Jakarta: PT.Grafindo Persada, 2006.

7. Farida $Y$, Khomsan A, Dwiriani C. Pengantar Pangan dan Gizi. Jakarta; Penerbit Buku Kedokteran ECG, 2004.

8. Wong D. Buku Ajar Keperawatan Pediatrik. Jakarta: Penerbit Buku Kedokteran ECG,2008.

9. Siegenthaler W. Differential Diagnosis in Internal Medicine: From Symptom to Diagnosis. Germany: Thieme Publishing Group, 2007.

10. Gunawan A. Food Combining. Jakarta: PT Gramedia Pustaka Utama, 2001.

11. Braun C, Anderson C. Pathophysiology: Functional Alterations in Human Health. Philadelphia; Lippincott Williams and Wilkins, 2007.

12. Burns D, Shah N. 100 Questions and Answers about Gastroesophageal Reflux Desease (GERD): a Lahey Clinic Guide. USA: Jones and Bartlett Publisher Inc, 2007.

13. Shinya $\mathrm{H}$. The Enzyme Factor. Oklahoma: Council Oak Books, 2007.

14. Ozner M. Heart Attack Proof: A Six- Week Cardiac Makeover for a Lifetime of Optimal Health. USA: BenBella Books Inc, 2012.

15. Suwardi, M. (2009). Al-Qur'an The Amazing Secret, Edisi Kesehatan. Jakarta: Ufuk Publishing House

16. Biro Lingkungan Hidup Surabaya. Profil Keanekaragaman Hayati Kota Surabaya Tahun 2012. Surabaya: BLH, 2012.

17. Khomsan A, Anwar F. Sehat itu Mudah: Wujudkan Hidup Sehat dengan Makanan Tepat. Jakarta: Penerbit Hikmah, 2008.

18. Hakim MN, Hakim R. How to Stop Poisoning Yourself the Pure and Natural Way. USA: Secretarius Memps Publications, 2008.

19. Larsson SC, Giovannucci E, Wolk A. Coffee Consumption and Stomach Cancer Risk in a Cohort of Swedish Women. International Journal of Cancer. 2006;119(9):2186-2189. 
20. Wu $Y$, Fan $Y$, Jiang $Y$, Wang $Y$, Liu $H$, Wei M. Analysis of Risk Factors Associated with Precancerous Lesion of Gastric Cancer in Patients from Eastern China: A Comparative Study. Journal of Cancer
Research and Therapheutics.2013;9:205209.

21. Remedios T. Gastronomical Problems: Spicy Food and the Explosive Effect. Available from: Diunduh 9 Agustus 2013. 
